\title{
Phenotypic variability in a family with x-linked adrenoleukodystrophy caused by the p.Trp132Ter mutation
}

\author{
Variabilidade fenotípica em uma família com adrenoleucodistrofia \\ ligada ao X causada pela mutação p.Trp132Ter
}

Fernanda Caroline Soardi', Adriana Mangue Esquiaveto-Aun 1,2, Gil Guerra-Júnior², Sofia Helena Valente de Lemos-Marini², Maricilda Palandi de Mello'

\footnotetext{
${ }^{1}$ Center for Molecular Biology and Genetic Engineering (CBMEG), Universidade Estadual de Campinas (Unicamp), Campinas, SP, Brazil 2 Pediatric Endocrinology, Department of Pediatrics, Faculdade de Ciências Médicas (FCM), Unicamp, Campinas, SP, Brazil
}

\section{SUMMARY}

X-linked adrenoleukodystrophy (X-ALD) is an inherited disease with clinical heterogeneity varying from presymptomatic individuals to rapidly progressive cerebral ALD forms. This disease is characterized by increased concentration of very long chain fatty acids (VLCFAs) in plasma and in adrenal, testicular and nervous tissues. Affected individuals can be classified in different clinical settings, according to phenotypic expression and age at onset of initial symptoms. Molecular defects in X-ALD individuals usually result from $A B C D 1$ gene mutations. In the present report we describe clinical data and the $A B C D 1$ gene study in two boys affected with the childhood cerebral form that presented with different symptomatic manifestations at diagnosis. In addition, their maternal grandfather had been diagnosed with Addison's disease indicating phenotypic variation for X-ALD within this family. The mutation p.Trp132Ter was identified in both male patients; additionally, three females, out of eleven family members, were found to be heterozygous after screening for this mutation. In the present report, the molecular analysis was especially important since one of the heterozygous females was in first stages of pregnancy. Therefore, depending on the fetus outcome, if male and p.Trp132Ter carrier, storage of the umbilical cord blood should be recommended as hematopoietic stem cell transplantation could be considered as an option for treatment in the future. Arq Bras Endocrinol Metab. 2010;54(8):738-43

\section{SUMÁRIO}

A adrenoleucodistrofia é uma doença genética com padrão de herança ligado ao X (X-ALD) que apresenta heterogeneidade clínica e varia desde a forma infantil cerebral severa até casos de indivíduos pré-sintomáticos. Essa doença é caracterizada pelo acúmulo de ácidos graxos de cadeia muito longa (VLCFA) no plasma, nas adrenais, nos testículos e no sistema nervoso. Indivíduos afetados podem apresentar diferentes formas clínicas, as quais são classificadas de acordo com a expressão fenotípica e a idade de aparecimento dos sintomas iniciais. Alterações moleculares em indivíduos com X-ALD são geralmente mutações no gene $A B C D 1$. No presente trabalho, descrevemos os dados clínicos e a investigação molecular do gene $A B C D 1$ em uma família com duas crianças do sexo masculino afetadas com a forma infantil cerebral, que apresentaram diferenças nas primeiras manifestações sintomáticas para o diagnóstico. Além disso, houve referência ao avô materno diagnosticado com doença de Addison's, indicando a variabilidade fenotípica da X-ALD nessa família. A análise molecular indicou a mutação p.Trp132Ter nos dois pacientes masculinos, e três indivíduos do sexo feminino, entre os onze estudados, mostraram-se heterozigotos para mutação. 0 conhecimento molecular descrito no presente relato adquiriu maior importância uma vez que uma das portadoras da mutação apresentou-se nos primeiros estágios de gestação. Assim, poderá ser oferecida a possibilidade de armazenamento de sangue de cordão umbilical para que se possa considerar, no futuro, o transplante de células-tronco hematopoiéticas como forma de tratamento, caso a criança seja do sexo masculino e afetada. Arq Bras Endocrinol Metab. 2010;54(8):738-43 


\section{INTRODUCTION}

$\mathrm{A}$ drenoleukodystrophy (X-ALD - MIM ID $\# 300100)$ is an inherited X-linked disease characterized by increased concentration of very long chain fatty acids (VLCFAs) in plasma that affects myelin, spinal cord, peripheral nerves, adrenal cortex and testis. The accumulation of VLCFA may also be observed in neonatal ALD, which is considered to be inherited as an autosomal recessive disorder. The incidence of X-ALD is estimated in 1:20.000 without differences among ethnic groups (1).

Affected individuals may present with different clinical forms that are classified according to phenotypic expression and age at initial symptoms (Table 1 ). When symptoms are observed before 10 years of age it is characterized as the childhood cerebral form. It manifests as progressive neurological damage with rapid evolution, leading to a vegetative state within six months to two years after onset of symptoms, followed by death at variable ages. The second form is the adrenomyeloneuropathy $(\mathrm{AMN})$, which presents initial symptoms in adult men with ages ranging from 20 years to middle-aged men. Affected individuals develop progressive weakness

Table 1. X-ALD phenotypes

\begin{tabular}{|c|c|c|c|}
\hline Phenotypes & $\begin{array}{c}\text { Clinical } \\
\text { manifestations }\end{array}$ & $\begin{array}{l}\text { Age at first } \\
\text { symptoms }\end{array}$ & Frequency \\
\hline \multicolumn{4}{|l|}{ Males } \\
\hline $\begin{array}{l}\text { Childhood } \\
\text { cerebral form }\end{array}$ & $\begin{array}{l}\text { Behavior changes, } \\
\text { school failure, } \\
\text { dementia, psychoses, } \\
\text { paralysis, epilepsy, loss } \\
\text { of vision, loss of speech }\end{array}$ & Before 10 years & $\sim 35 \%$ \\
\hline AMN & $\begin{array}{l}\text { Paraparesis, sphincter } \\
\text { disturbances, sensory } \\
\text { changes, loss of } \\
\text { coordination, pain, } \\
\text { impotence }\end{array}$ & $\begin{array}{c}\text { Between } 2^{\text {nd }} \text { and } \\
4^{\text {th }} \text { decades }\end{array}$ & $\begin{array}{c}\sim 40 \% \text { to } \\
45 \%\end{array}$ \\
\hline $\begin{array}{l}\text { Addison's } \\
\text { disease only }\end{array}$ & $\begin{array}{l}\text { Adrenocortical } \\
\text { insufficiency }\end{array}$ & $\begin{array}{l}\text { Between } 2 \text { years } \\
\text { and adulthood }\end{array}$ & $\sim 10 \%$ \\
\hline AMN cerebral & $\begin{array}{c}\text { Pure AMN plus } \\
\text { dementia-like } \\
\text { behavioral disturbances, } \\
\text { psychosis, epilepsy, } \\
\text { aphasia, visual loss }\end{array}$ & $\begin{array}{c}\text { Between } 10 \text { and } \\
21 \text { years }\end{array}$ & $\sim 5$ to $10 \%$ \\
\hline Asymptomatic & None & $\begin{array}{c}\text { Older than } 60 \\
\text { years }\end{array}$ & Increasing \\
\hline \multicolumn{4}{|l|}{ Females } \\
\hline Asymptomatic & None & Any age & $\sim 50 \%$ \\
\hline $\begin{array}{l}\text { Symptomatic } \\
\text { carriers }\end{array}$ & $\begin{array}{l}\text { AMN (paraparesis) like } \\
\text { with normal adrenal } \\
\text { function }\end{array}$ & $\begin{array}{c}\text { Middle-aged or } \\
\text { later }\end{array}$ & $\sim 50 \%$ \\
\hline
\end{tabular}

in the legs, sphincter control abnormalities, and may also have serious cognitive and behavioral disturbances over the decades. A third variant is the cerebral AMN form that presents similar neurological findings in association with some other characteristics such as dementia or psychosis. These symptoms arise between 10 and 21 years of age denoting a delayed onset with slow evolution rates. The fourth form that can be distinguished is Addison's disease, which accounts for only $10 \%$ of affected individuals. In this case, initial signs appear at different ages between two years of age and adulthood $(1,2)$. Additionally, asymptomatic forms have been identified in older men (3). Although it is an X-linked disease, 50\% of female carriers may develop AMN signals manifesting as mild to moderate spastic paraparesis in middle-aged women or later with normal adrenal function (4).

$\mathrm{X}$-ALD is caused by mutations in the ATP-binding cassette, subfamily $\mathrm{D}$, member 1 gene $(A B C D I$ - MIM ID *300371). $A B C D 1$ gene is located at $\mathrm{Xq} 28$ and encodes a peroxisomal adenosin triphosphate (ATP) binding cassette transporter protein (ABCDl, ALDP) that plays a crucial role in VLCFA transport, or their coenyme $\mathrm{A}(\mathrm{CoA})$ derivatives into peroxisomes $(5,6)$. If the protein function is impaired no beta oxidation of VLCFAs occurs and they accumulate in body fluids and tissues leading either to neuroinflammation and demyelination in the brain characterizing the cerebral childhood form or to axonal degeneration in spinal cord in AMN (7). The mechanisms of the disease pathogenesis remain unclear whereas it is possible that VLCFA cytotoxicity causes oxidative stress with subsequent neuroinflammation followed by generalized peroximal dysfunction (8).

Neither VLCFA plasma concentration nor the type of mutation can usually predict the phenotype of X-ALD because a same $A B C D 1$ gene mutation can be associated with different phenotypes (9-12).

The present study reports the phenotypic variability and the molecular investigation in a family with two affected male cousins with X-linked adrenoleukodystrophy. The $A B C D I$ gene sequencing indicated p.Trpl32Ter mutation segregation in affected male individuals and in normal female carriers.

\section{SUBJECTS AND METHODS}

\section{Clinical data}

Case 1 is a previously healthy boy who presented the first symptoms at the age of 6 years. For the last eight 
months he has manifested vomiting and hyponatraemia once a week. These episodes were followed by pronounced dehydration and hypoglycemia. Mild difficulty in speech and some hyperactivity were observed. Family history reported that two members of his maternal family had deceased without a defined diagnosis: his grandfather, who died at the age of 44 years, had suffered recurrent episodes of fainting and presented clinical data suggestive of Addison's disease; and, a cousin, who started with neurological deficits at the age of 17 years, developed into total disability and died when he was 21 years old, after a period of vegetative life (Figure 1A). Hormonal dosages for Case 1 showed high ACTH levels (Table 2); therefore glucocorticoid replacement therapy was initiated for adrenal insufficiency. His neurological abilities have worsened with progressive impairment of cognition and behavior. A brain magnetic resonance imaging (MRI) exam revealed ventricular asymmetry on the right side with an enhanced T-2 signal. He is now 7 years old, presents generalized hypotonia, difficulties in understanding spoken language, and hearing deficit.

Case 2 is a previously healthy boy with excellent performance at school, who was 8 years old when he started with attention deficit disorder, last year. Four months after that, he manifested difficulties in dressing and walking. Rapidly, he presented loss of vision and hearing. Treatment with Lorenzo's oil was introduced after signs of X-ALD had been observed in brain MRI. Laboratorial evaluation revealed high ACTH level (Table 2), therefore glucocorticoid and mineralocorticoid replacement therapies were initiated, even before clinical signs of adrenal insufficiency could be observed. He is now 9.6 years old and lives in a vegetative state.

Table 2. Laboratorial adrenal evaluation at diagnosis.

\begin{tabular}{lccc}
\hline & Method & Case 1 & Case 2 \\
\hline $\mathrm{Na}^{+}(\mathrm{mmol} / \mathrm{L})$ & $\mathrm{ISE}^{1}$ & 111 & 137 \\
$\mathrm{~K}^{+}(\mathrm{mmol} / \mathrm{L})$ & $\mathrm{ISE}^{1}$ & 6.1 & 4.9 \\
$\mathrm{ACTH}(\mathrm{pg} / \mathrm{mL})$ & ${\mathrm{EIA}-\mathrm{CL}^{2}}$ & 516 & 2322 \\
Basal cortisol $(\mu \mathrm{g} / \mathrm{dL})$ & ${\mathrm{EIA}-\mathrm{CL}^{3}}$ & 12.2 & 5.86 \\
Plasmatic renin activity $(\mathrm{pg} / \mathrm{mL})$ & $\mathrm{IRMA}^{4}$ & 17.7 & $>520$ \\
\hline
\end{tabular}

${ }^{1}$ Ion selective electrode; ${ }^{2}$ Chemiluminescence Enzyme Immunoassay - normal range up to 46 $\mathrm{pg} / \mathrm{mL} ;{ }^{3}$ Electrochemiluminescence Enzyme Immunoassay - normal range 2.5 to $12.5 \mu \mathrm{g} / \mathrm{dL}$; ${ }_{4}^{4}$ Immunoradiometric assay -normal range 2.4 to $21.6 \mathrm{pg} / \mathrm{mL}$.

\section{Molecular analysis}

This study was approved by the Ethics Committee of the Universidade Estadual de Campinas (São Paulo, Brazil) and informed consents from family members were obtained.

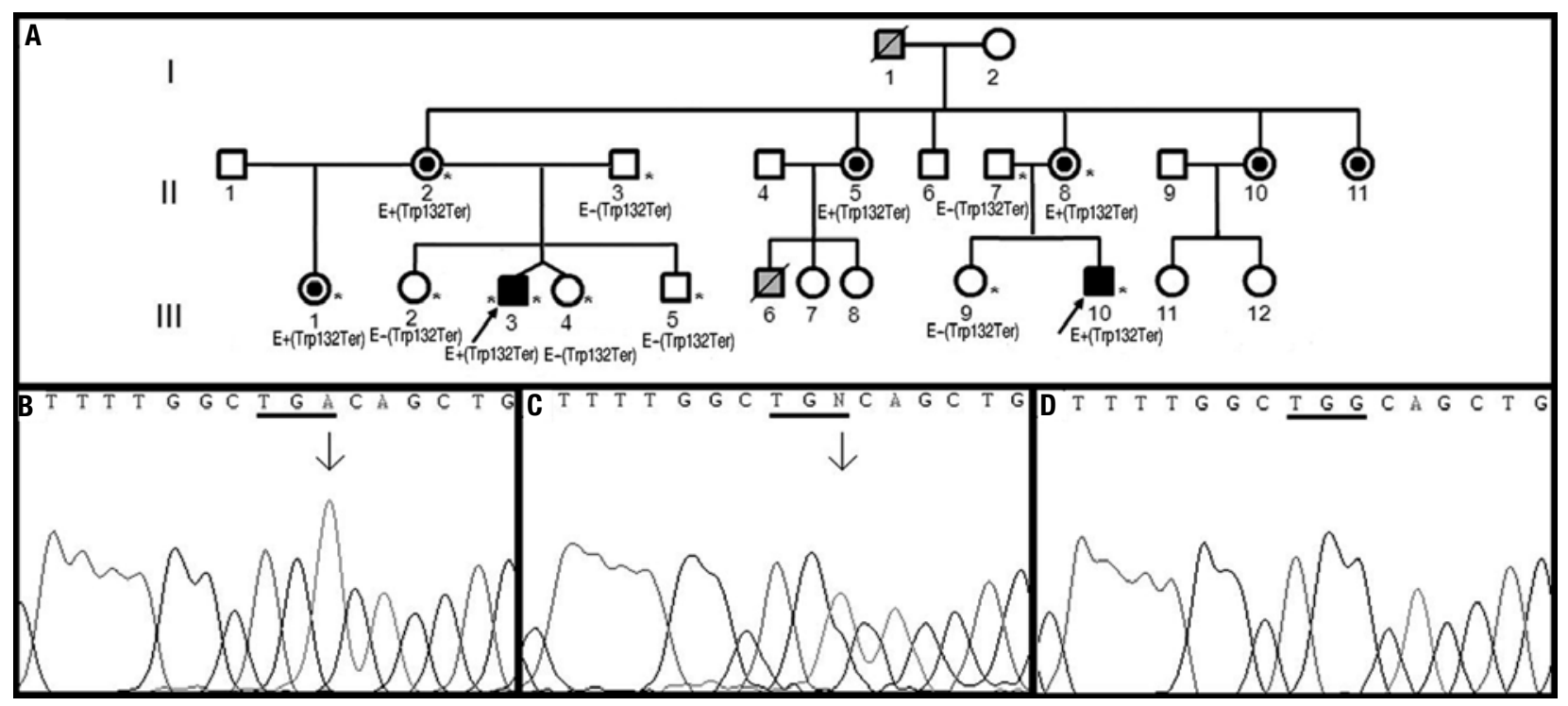

Figure 1. (A) X-ALD family pedigree. Twelve family members were molecularly evaluated; arrows indicate index cases. Individuals II.2, II.5, II.8, II.10 and II.11 are obligate carriers. Asterisks denote individuals that were personally examined. E+(p.W132Ter) and E-(p.W132Ter) indicate that the individuals have been molecularly evaluated for the mutation and are either affected (males) or carriers (females) and normal, respectively. Individuals I.1 and III.6 have not been studied however clinical history indicated that they were X-ALD affected individuals. (B-D) Electropherograms for exon 1 ABCD1 gene partial nucleotide sequence: DNA sequence with the $G>A$ nucleotide change forming a TGA stop codon, the arrow indicates position of the nucleotide change. (C) heterozygosis for $\mathrm{G}>\mathrm{A}$ nucleotide change observed in three females; (D) ABCD1 sequence denoting the normal TGG codon for tryptophan in residue 132. 
Genomic DNA from peripheral leukocytes was purified by proteinase Klysis, phenol/chloroform extraction and ethanol precipitation using standard techniques (13). Each exon of the $A B C D I$ gene and its respective flanking regions were amplified by PCR from genomic DNA using primers designed with GeneRunner v3.1 free software (Table 3 ). PCR products were purified in $1 \%$ agarose gel electrophoresis with the Wizard ${ }^{\circledast}$ SV Gel \& PCR clean-up system (Promega, USA), and both sense and antisense strands were sequenced with the BigDye Terminator v3.1 Cycle Sequencing Kit (Applied Biosystems, USA) using the same primers as for the PCR reactions. Chromas Lite and CLC Sequence Viewer v.5.0.1 free softwares were used to analyze and compare sequences with the reference $A B C D I$ gene sequence (ENSG00000101986, www.ensembl.org).

Table 3. Primers designed for amplification and sequencing of $A B C D 1$ gene

\begin{tabular}{|c|c|c|c|}
\hline Primer & Sequence (5'-3') & $\mathrm{T}_{\mathrm{a}}\left({ }^{\circ} \mathrm{C}\right)^{1}$ & Size $(\mathbf{b p})^{2}$ \\
\hline 5'UTRs & GGAGAAGGTGGAGAGGAAGAGA & 62.2 & 1356 \\
\hline Int1as & GGCCTGCCCACACCTTTG & 62.9 & \\
\hline${\text { Ex } 1 s^{3}}^{2}$ & GGAGACGGGGCTGCTGGC & 67.0 & \\
\hline Ex1as $^{3}$ & CGACAGGAAGGTGCGGCTC & 65.0 & \\
\hline Int1s & CAGCGTGTGTGAGTGGCA & 57.2 & 717 \\
\hline Int2as & GGCTTCCСАСTCСTCTAAA & 55.7 & \\
\hline Int2s & GCAGAAGAGCCTCGCCT & 56.6 & 621 \\
\hline Int4as & CAGAAGCACATGGAGGTCC & 56.5 & \\
\hline Int4s & GACCTGGCTGTGTTCCCTAG & 58.4 & 483 \\
\hline Int5as & CCTTGGTCAATCCTGGTATCA & 58.9 & \\
\hline Int5s & GAGATCAAGAATGGCCTGC & 56.3 & 931 \\
\hline Int7as & СССТTCCCTAGAGCACCTG & 58.4 & \\
\hline Int7s & GCACGATTCCAGTCCCCAC & 61.7 & 1077 \\
\hline 3'UTRas & CGCCACССТССАСАТСТАСТ & 61.2 & \\
\hline $\mathrm{Ex}^{3} \mathrm{~s}^{3}$ & CTGCTCTCCATCACCCACCG & 64.7 & \\
\hline Int9as ${ }^{3}$ & CAGGCAGGGAGACAGGGC & 61.8 & \\
\hline
\end{tabular}

${ }^{1}$ Anealing temperature used in PCR; ${ }^{2}$ Size of amplified fragments; ${ }^{3}$ Internal primers used for sequencing only.

\section{RESULTS}

Clinical and laboratorial data indicated that in Case 1 , the initial presentation was adrenal insufficiency followed by mild to moderated neurological manifestations, whereas in Case 2 neurological damage was the first sign that evolved rapidly and drastically to a severe condition without clinical indicatives of adrenal insufficiency.

$A B C D I$ sequence analysis of the affected individuals revealed the nucleotide change TGG $>$ TG $\underline{A}$ within exon 1 (Figure 1B, C, D). This change creates a stop codon at residue 132 and causes the nonsense mutation p.Trpl32Ter. The screening for p.Trpl32Ter mutation in the family revealed three heterozygous females out of eleven evaluated members (Figure 1A).

\section{DISCUSSION}

The present report describes a family with two boys affected by X-linked adrenoleukodystrophy. The study of the $A B C D 1$ gene revealed mutation p.Trpl32Ter as responsible for the disease. Three female members of the family were found to carry the mutation including the pregnant sister of the index case. This nonsense mutation was previously described in a patient with childhood cerebral adrenoleukodystrophy (11) additionally, the X-ALD Mutation Database (http://www.X-ald.nl/ mutations-gene/mutations-in-abcdl) refers to three other unpublished cases with the p.Trp132Ter mutation. There are 1,133 mutations annotated for $A B C D 1$ gene in the Mutation Database last updated on November $12^{\text {th }}, 2010$ and almost $50 \%$ are recurrent. According to database's statistics $10 \%$ of total mutations are nonsense, $22 \%$ are frameshift, $61 \%$ are missense, and the other $7 \%$ correspond to insertions or deletions. There are some residues in ALDP that seem to be more susceptible to mutations since the same mutation or different mutations in the same amino acid have been described in different studies (Figure 2). However, they do not represent mutation hotspots since they occur in almost every exon, except in exons 2,4 and 10. Although expression and functional studies for p.Trpl32Ter mutation have not been performed, it is putatively considered to result in the absence of ALDP likewise $74 \%$ of all mutations identified in $A B C D 1$ gene.

The two patients described here as carrying the same mutation, present the childhood cerebral form of the disease although Case 1 has presented clinical signs of adrenal insufficiency more evidently than Case 2. It is well known that more than one clinical phenotype can manifest within a single X-ALD pedigree $(9,10,12)$. Mild phenotypes have been described for some frameshift and nonsense mutations which are generally predicted to form a truncated transcript $(12,14)$. This variability suggests that the X-linked adrenoleukodystrophy phenotype may be influenced to a great extent by other genetic or environmental factors $(8,11)$. As the family investigation progressed the information that the maternal grandfather presented Ad- 


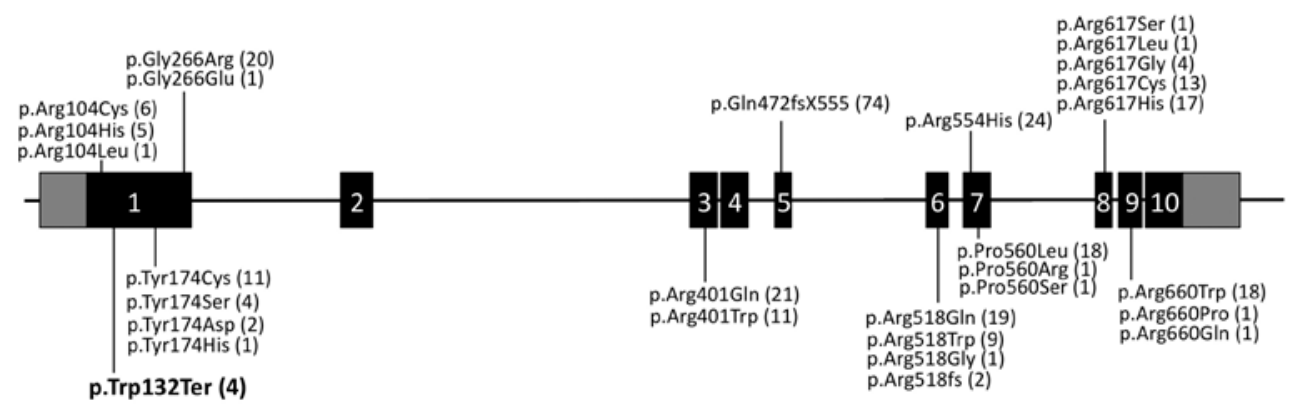

Figure 2. Schematic representation of the 10 exons of $A B C D 1$ gene. Amino acid residues at which more than ten cases have been reported with different mutations are denoted. Numbers of reported cases are in parenthesis. The mutation described in this report is represented in bold.

dison's disease was obtained. Considering that he probably carried the mutation, it can be inferred there is a second clinical form for p.Trp132Ter within the family. These data confirm phenotypic variability for $A B C D 1$ gene mutations already reported by others $(11,12,15)$ and suggest that modifier genes or environmental/epigenetic/stochastic factors might modulate the clinical outcome of the disease (8).

As the X-ALD diagnosis is established, steroid replacement therapy is mandatory to prevent the consequences of adrenocortical insufficiency and may be life saving, but it does not alter the rate of neurologic progression $(2,16)$. In fact, there is no correlation between adrenal involvement and the type of neurologic involvement or the rate of neurologic progression (14). In order to impair the neuroinflammatory demyelinating process of X-ALD, hematopoietic stem cell transplantation (HSCT) can be performed at early stages of the disease $(17,18)$, before manifestation of any significant neurologic deficits, when limited extensions of the lesion can be observed upon brain MRI (19). In fact, HSCT is mostly limited to patients at the stage of initial signs of Addison's disease or those asymptomatic individuals within a family who have been identified during genetic counseling $(1,20)$. Actually, HSCT is mostly recommended for AMN patients with cerebral involvement (19). There are two other treatments available for patients with X-ALD: corticosteroid replacement therapy, indicated for Addison's disease, and Lorenzo's oil therapy. Lorenzo's oil is a 4:1 mixture of glyceryl-trioleate and glyceryl-trierucate, which normalizes plasma VLCFA levels in X-ALD patients but does not impair progression of cerebral lesion (2). Its clinical efficacy and the clinical indications for its use are still controversial (20). Novel therapies have been tentatively tested. Recent trials have shown that neither immunosuppressive/immunomodulating therapies nor lovastatin treat- ment were useful for patients with cerebral damage. Antioxidative treatments could possibly be a future therapeutic option as they are considered to have some neuroprotective effect $(19,21)$. Nevertheless, molecular testing is an important tool to have in hands since it contributes not only for diagnosis, especially when the analysis of VLCFAs in plasma is not available, but also for genetic counseling purposes as in the family here described. In addition, when an $A B C D I$ mutation is identified in asymptomatic affected males they might be candidates for HSCT to prevent neurodegenerative processes $(17,18)$.

Finally, analysis of the $A B C D 1$ gene in women within an affected family can provide information about the origin of the disease but, most important, is that it provides the possibility of evaluating the risk of transmission because of the X-linked maternal inheritance of the disease (11). In the present family, individual III.1 that was found to be heterozygous for the p.Trp132Ter mutation is at the first stages of pregnancy. Consequently, depending on the fetus outcome, if male and p.Trp132Ter carrier, the umbilical cord blood storage should be recommended as HSCT could be considered in the future.

Acknowledgements: The authors would like to thank Dr. Márcio José da Silva from CBMEG sequencing facility for technical support.

Disclosure: no potential conflict of interest relevant to this article was reported.

\section{REFERENCES}

1. Moser AB, Steinberg SJ, Raymond GV. In: Pagon RA, Bird TC Dolan CR, Stephens K, editors. GeneReviews [Internet]. Seattle (WA): University of Washington, Seattle; 1993-1999 Mar 26 [updated 2009 Jun 2].

2. Moser HW, Raymond GV, Dubey P. Adrenoleukodystrophy: new approaches to a neurodegenerative disease. JAMA. 2005;294(24):3131-34. 
3. Schönberger S, Roerig P, Schneider DT, Reifenberger G, Göbel U, Gärtner J. Genotype and protein expression after bone marrow transplantation for adrenoleukodystrophy. Arch Neurol. 2007;64:651-7.

4. Moser HW, Smith KD, Watkins PA, Powers J, Moser AB. X-linked adrenoleukodystrophy. In: Scriver CR, Beaudet AL, Sly WS, Valle $D$, editors. The metabolic and molecular bases of inherited disease. NewYork: McGraw Hill; 2001. p. 3257-301.

5. Mosser J, Douar AM, Sarde CO, Kioschis P, Feil R, Moser H, et al. Putative $X$-linked adrenoleukodystrophy gene shares unexpected homology with ABC transporters. Nature. 1993;361:726-30.

6. Higgins $C F . A B C$ transporters: from microorganisms to man. Ann Rev Cell Biol. 1992;8:67-113.

7. Kim JH, Kim HJ. Childhood X-linked adrenoleukodystrophy: clinical-pathologic overview and MR imaging manifestations at initial evaluation and follow-up. Radiographics. 2005;25(3):619-31.

8. Singh I, Pujol A. Pathomecanisms underlying $X$-adrenoleukodistrophy: a three-hit hypothesis. Brain Pathol. 2010;20:838-44.

9. Power JM. Adreno-leukodystrophy (adreno-testiculo-leukomyeIoneuropathiccomplex). Clin Neuropathol. 1985;4:191-99.

10. Power JM, LiuY, Moser AB, Moser HW. The inflammatory myelinopathy of adrenoleukodystrophy: cells, effector molecules, and pathogenetic implications. J Neuropathol Exp Neurol. 1992;51:630-43.

11. Pan $\mathrm{H}$, Xiong $\mathrm{H}, \mathrm{Wu} Y$, Zhang $\mathrm{YH}$, Bao $\mathrm{XH}$, Jiang $\mathrm{YW}$, et al. ABCD1 gene mutations in Chinese patients with $X$-linked adrenoleukodystrophy. Pediatr Neurol. 2005;33:114-20.

12. Takano $H$, Koike R, Onodera O, Sasaki R, Tsuji S. Mutational analysis and genotype-phenotype correlation of 29 unrelated Japanese patients with X-linked adrenoleukodystrophy. Arch Neurol. 1999;56:295-300.
13. Sambrook J, Fritsch EF, Maniatis TE. Molecular cloning, a laboratory manual. Cold Spring Harbor, NewYork. 1989.

14. Cartier N, Aubourg P. Hematopoietic stem cell transplantation and hematopoietic stem cell gene therapy in X-linked adrenoleukodystrophy. Brain Pathol. 2010;20:857-62.

15. Krasemann EW, Meier V, Korenke GC, Hunneman DH, Hanefeld F. Identification of mutations in the ALD-gene of 20 families with adrenoleukodystrophy/ adrenomyeloneuropathy. Hum Genet. 1996;97:194-97.

16. Kemp S, Pujol A, Waterham HR, van Geel BM, Boehm CD, Raymond GV, et al. ABCD1 mutations and the X-linked adrenoleukodystrophy mutation database: role in diagnosis and clinical correlations. Hum Mut. 2001;18:499-515.

17. Mahmood A, Dubey P, Moser HW, Moser A. X-linked adrenoleukodystrophy: therapeutic approaches to distinct phenotypes. Pediatr Transplant. 2005;9(7):55-62.

18. Shapiro E, KrivitW, Lockman L, Jambaque I, Peters C, Cowan M, et al. Long-term effect of bone-marrow transplantation for childhood-onset cerebral X-linked adrenoleukodystrophy. Lancet. 2000;356:713-8.

19. Peters C, Charnas LR, Tan Y, Ziegler RS, Shapiro EG, DeFor T, et al. Cerebral $\mathrm{X}$-linked adrenoleukodystrophy: the international hematopoietic cell transplantation experience from 1982 to 1999. Blood. 2004;104:881-8.

20. Berger J, Pujol A, Aubourg P, Forss-Petter S. Current and future pharmacological treatment strategies in X-linked adrenoleukodistrophy. Brain Pathol. 2010;20(4):845-56.

21. Halliwell B. Role of free radicals in the neurodegenerative diseases: therapeutic implications for antioxidant treatment. Drugs Aging. 2001;18:685-716. 